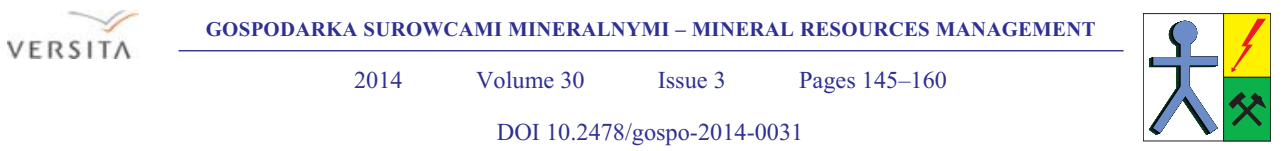

\title{
Badanie suszenia słomy i węgla brunatnego w suszarce multicyklonowej
}

\section{Wprowadzenie}

Dotychczasowa gospodarka surowcami energetycznymi polega na użytkowaniu każdego z paliw stałych oddzielnie, ewentualnie współspalaniu biomasy z węglem, które nie jest najlepszym sposobem utylizacji tych paliw (Mirowski i Surma 2008). Wytwarzanie paliw kompozytowych z węgla i biomasy stanowi nowe podejście do procesów konwersji paliw stałych. Jest to sposób na uzyskanie paliwa charakteryzującego się stabilnymi parametrami użytkowymi, co jest bardzo istotne dla jego potencjalnych odbiorców. Operacja scalania węgla i biomasy stwarza bowiem nie tylko możliwość zwiększenia tzw. gęstości energetycznej biomasy, ale również okazję do wprowadzenia do składu paliwa dodatków, które dzięki swoim specyficznym właściwościom fizykochemicznym pozwalają podnieść wartość użytkową uzyskanego kompozytu (Hryniewicz i in. 2012). Proces wytwarzania tych paliw na bazie odpadów z produkcji rolnej i ich mieszanek z odpadowymi węglami wymaga wcześniejszego przygotowania surowców. Bezlepiszczowe granulowanie biomasy roślinnej w peletyzatorach to proces wymagający zachowania określonych warunków przygotowania tego paliwa. Głównymi parametrami decydującymi o przebiegu procesu scalania są zawartość wilgoci, homogenność i rozmiar ziaren nadawy. Wymagana zawartość wilgoci powinna mieścić się w przedziale 12-16\%. Jednocześnie mieszanka surowcowa powinna

* Dr inż., AGH Akademia Górniczo-Hutnicza, Wydział Inżynierii Mechanicznej i Robotyki, Katedra Systemów Wytwarzania, Kraków; e-mail: t.dzik@agh.edu.pl

** Dr inż., AGH Akademia Górniczo-Hutnicza, Wydział Energetyki i Paliw, Kraków; e-mail: gczerski@agh.edu.pl 
charakteryzować się jednolitą zawartością wilgoci w całej objętości. Surowiec pozyskiwany w postaci słomy zbóż w balotach posiada zawartość wilgoci od 6 do 30\%, a jej rozkład jest bardzo nierównomierny. W związku z powyższym przed procesem scalania wymagane jest podsuszenie surowca. Celem suszenia jest ujednorodnienie rozkładu wilgoci nadawy oraz uzyskanie wilgotności w wymaganym przedziale. Węgiel brunatny, stanowiący składnik paliw kompozytowych, pozyskiwany ze złoża posiada zawartość wilgoci od 14 do $70 \%$ i też wymaga procesu suszenia. Do suszenia zarówno biomasy jak i węgla w celu przygotowania tych paliw do procesu scalania z powodzeniem wykorzystać można suszarkę multicyklonową, stanowiącą oryginalne rozwiązanie konstrukcyjne opracowane przez AGH. Ponadto suszarkę tę można stosować również do innych celów, jak np. podsuszanie wsadu węglowego w procesie koksowania w celu poprawy jakości produkowanego koksu (Karcz i Strugała 2008; Żarczyński i in. 2013).

\section{Suszenie surowców energetycznych}

Obecnie stosowne są różne technologie suszenia biomasy: suszenie słomy w balotach, suszenie biomasy rozdrobnionej wstępnie lub po jej finalnym rozdrobnieniu. Ze względu na zapewnienie jak największej wartości współczynnika wymiany ciepła, co skraca czas suszenia i wpływa na rozmiary urządzeń suszących, stosuje się technologie suszenia nadawy po jej finalnym rozdrobnieniu (Mujumda 2011). Najczęściej stosuje się technologie, w których zastosowano suszarki: pneumatyczno-rurowe (a), z prądem wstecznym (b), cyklonowe (c), bębnowe (d), taśmowe (e) i fontannowe (f), a ich schematy przedstawiono na rysunku 1 .

W przemyśle najchętniej stosowane są rozwiązania wykazujące jak największy współczynnik wymiany ciepła, możliwie najmniejsze wymiary i pozwalające uzyskać jak najlepszą homogenizację, $\mathrm{tj}$. suszarki pneumatyczno-rurowe, z prądem wstecznym, cyklonowe i fontannowe. Dodatkową cechą wyróżniającą tego typu suszarki jest średni lub niski poziom zagrożenia pożarowego. Suszarka pneumatyczno-rurowa charakteryzuje się prostotą konstrukcji, małą koncentracją nadawy w czynniku suszącym i wysoką intensywnością procesu, szczególnie w dolnym odcinku rury. Krótki czas pobytu cząstek w strefie suszenia (zazwyczaj poniżej 1-2 sekund) pozwala wykorzystać wysokie początkowe wartości temperatury czynnika suszącego bez niebezpieczeństwa przegrzania wysuszanego materiału. Podstawowym mankamentem tego rozwiązania jest duże zapotrzebowanie na czynnik suszący dla zapewnienia procesu suszenia i stałego przemieszczenia wszystkich frakcji suszonego materiału.

Krótki czas przebywania surowca w suszarkach pneumatyczno-rurowych często nie pozwala wysuszać w nich materiałów do wymaganej wilgotności. Naturalnym jest więc dążenie do zmniejszenia szybkości ruchu ziaren i tym samym zwiększenia czasu ich pobytu w strefie suszenia. Przy tym jednocześnie intensyfikuje się proces wymiany ciepła i masy. Sposób częściowego hamowania ziaren suszonego materiału realizuje się w suszarkach 
a)

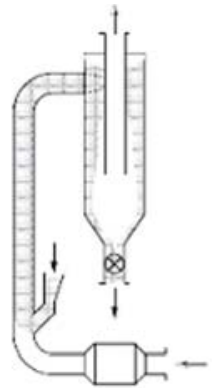

d)

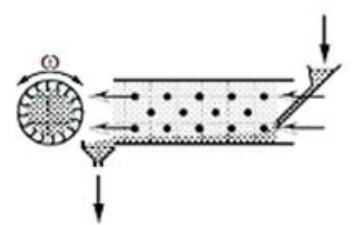

b)

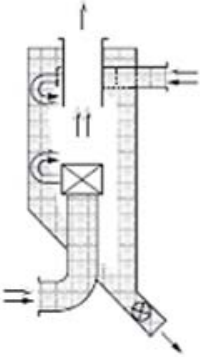

e)

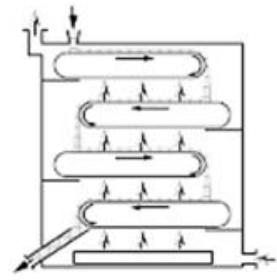

c)

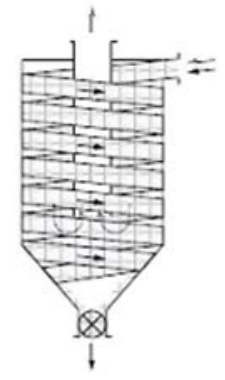

f)

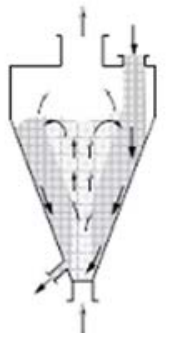

Rys. 1. Suszarki stosowane do suszenia rozdrobnionej biomasy roślinnej (Hryniewicz i in. 2012) a) pneumatyczno-rurowe; b) z prądem wstecznym; c) cyklonowe; d) bębnowe; e) taśmowe; f) fontannowe

Fig. 1. Diagrams of dryers used for drying ground plant-derived biomass

a) a pneumatic-tubular dryer; b) a counter-current dryer; c) a cyclone dryer; d) a drum dryer; e) a belt dryer; f) a fountain dryer

cyklonowych. Ziarna w cyklonie posuwają się po wewnętrznej powierzchni cyklonu. Analiza dynamiki ruchu ziaren w suszarce cyklonowej wykazuje złożony ruch ze względu na zmienne działanie siły dynamicznego oddziaływania ruchu obrotowego potoku czynnika suszącego i siły tarcia ziaren o wewnętrzną ściankę cyklonu. Współczynnik tarcia ziaren o ściankę jest funkcją ich właściwości i formy oraz stanu powierzchni ścianki cyklonu. Obserwacje pokazują, że po wewnętrznej ściance cyklonu cząstki przesuwają się zazwyczaj w formie wstążki spiralnej (Westbergh 2007; Bunyawanichakul 2006). Wewnątrz posuwającej się w dół wstążki rozdrobniony materiał obtacza się po ścianie komory, co wywołuje dodatkowy kontakt z nagrzanym elementem oraz zwiększa prędkość ziaren względem czynnika suszącego. Takie rozwiązanie pozwala na uzyskanie współczynnika wymiany ciepła o wartościach do $250 \mathrm{~W} / \mathrm{m}^{2} \mathrm{~K}$. Wymiana ciepła w suszarkach z jednym cyklonem w przypadku suszenia rozdrobnionej słomy wykazuje zbyt krótki czas działania czynnika suszącego, małą sprawność oraz zbyt niski stopień ujednorodnienia rozkładu wilgoci.

Alternatywą dla tego rozwiązania jest suszarka multicyklonowa, stanowiąca oryginalne rozwiązanie konstrukcyjne opracowane przez AGH i zgłoszone do opatentowania (Dzik i Grzebieluch 2012). Proces suszenia dokonuje się w trzech, połączonych szeregowo cyklonach w taki sposób, że odejście gazu z cyklonu poprzedniego stanowi wejście gazu do cyklonu następnego (rys. 2). Nagrzany w nagrzewnicy gaz suszący wprowadzany jest do cyklonu (1) najniższego stopnia poprzez rurę dolotową (7). Do rury dolotowej cyklonu (1) surowiec podawany jest po podsuszeniu i wydzieleniu w cyklonie (2) za pomocą podaj- 


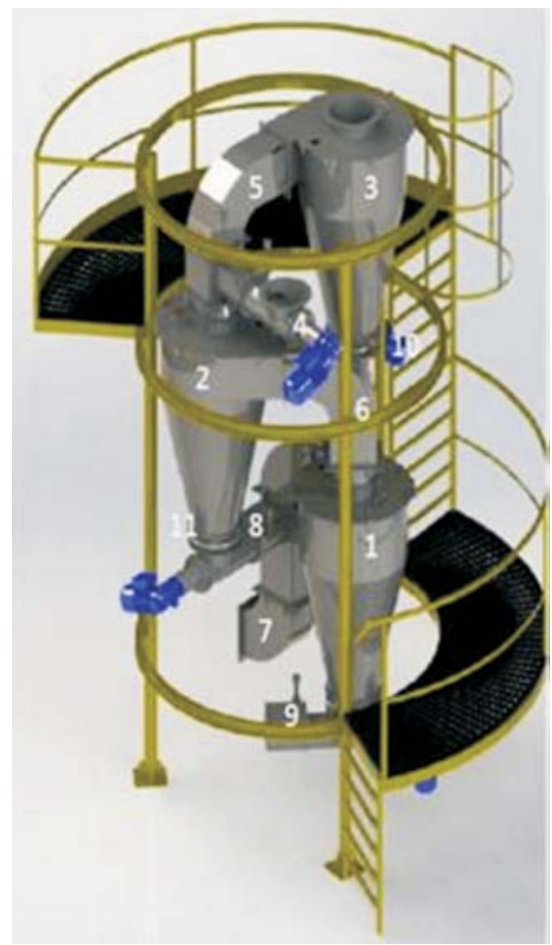

Rys. 2. Suszarka multicyklonowa

Fig. 2. A multi-cyclone dryer

nika (8). Po oddaniu ciepła oraz przejęciu wilgoci gaz z cyklonu (1) kierowany jest do rury (6) i za jej pomocą wprowadzany stycznie do cylindrycznej części cyklonu (2). Jednocześnie do rury (6) podawany jest za pomocą podajnika (10) surowiec wydzielony w cyklonie (3). Mokry pierwotny materiał dozowany jest do suszarki za pomoca podajnika (4) do rury (5) odbierającej gaz z cyklonu (2). Istotnym elementem rozwiązania konstrukcyjnego suszarki multicyklonowej jest układ wybierania wydzielonego w cyklonach surowca i jego dozowania na następny stopień przy zachowaniu szczelności hydraulicznej między poszczególnymi stopniami suszarki i właściwym dozowaniu do każdego stopnia suszarki. Taki układ obiegu biomasy nadaje suszarce wysoką sprawność, wydłuża czas przebywania materiału w suszarce, powoduje równomierny rozkład zawartości wilgoci w całej objętości masy oraz umożliwia podgrzanie surowca do temperatury $60^{\circ} \mathrm{C}$. Do transportu surowca wykorzystano podajniki ślimakowe. Czynnikiem suszącym jest powietrze podgrzane w ogrzewaczu spalającym olej opałowy. Temperatura czynnika suszącego jest regulowana w zakresie od 25 do $250^{\circ} \mathrm{C}$ w zależności od potrzeb. W suszarce może być suszony surowiec, którego wilgotność początkowa wynosi do $35 \% \mathrm{w}$ przypadku biomasy (słoma, miskantus) i do $50 \%$ w przypadku węgla brunatnego. Takie rozwiązanie konstrukcyjne pozwala również na intensywne mieszanie, wspólne podsuszanie i homogenizację mieszanki rozdrobnionej słomy i miałów węgla brunatnego lub kamiennego. 
Doświadczalne stanowisko badawcze prototypu suszarki multicyklonowej o wydajności $500 \mathrm{~kg} / \mathrm{h}$ jest obecnie zainstalowane w zakładzie produkującym pelet ze słomy do celów energetycznych w firmie EKO GAW współpracującej z AGH. W suszarce tej jako źródło ciepła wykorzystano olejową nagrzewnicę powietrza o mocy cieplnej $60 \mathrm{~kW}$ i wydatku $3000 \mathrm{Nm}^{3} / \mathrm{h}$. Ze względu na niewystarczający spręż wentylatora nagrzewnicy zastosowano dodatkowy wentylator ssący podłączony do rury wylotowej cyklonu (3). Gazy odlotowe kierowane są do odpylacza tkaninowego. Suszarka została wyposażona w elementy pomiarowe, pozwalające na ciaggły pomiar temperatury gazu suszącego oraz surowca na wejściu do instalacji i po wysuszeniu.

\section{Pomiary oraz modelowanie pracy suszarki multicyklonowej}

Do utworzenia modelu numerycznego CFD (Computational Fluids Dynamics) procesu suszenia w suszarce multicyklonowej wykorzystano oprogramowanie ANSYS Fluent. Numeryczny model CFD suszarki multicyklonowej można wykorzystać w różnorodny sposób, tj.:

- do uzyskania danych, których pozyskanie na drodze pomiarowej jest niemożliwe lub bardzo trudne,

- do prowadzenia obliczeń dla rożnych warunków pracy suszarki (różnych paliw, różnych wydajności, zawartości wilgoci w paliwie, uziarnienia itd.).

Geometrię układu przygotowano za pomocą aplikacji Design Modeler zawartej w pakiecie ANSYS, natomiast siatkę obliczeniową wykorzystując do tego aplikację Mesh, która również jest częścią oprogramowania ANSYS. Bardzo istotnym zagadnieniem przy modelowaniu przepływu płynu jest odpowiedni dobór modelu turbulencji. W szeregu publikacji (Brennan i in. 2009; Corrê i in. 2004; Wang i in. 2003) dotyczących modelowania CFD w cyklonach jako właściwy model turbulencji zaleca się stosowanie Reynolds Stress Model (RSM), ewentualnie LES (Large Eddy Simulations). Ten ostatni wymaga jednak znacznie więcej mocy obliczeniowych i czasu do prowadzenia obliczeń, stąd w prowadzonych symulacjach wykorzystano model RSM. Do modelowania przepływu wielofazowego zastosowano Lagrangian Discrete Phase Model (DPM). W modelu tym płyn jest traktowany jako faza ciagła, natomiast dla fazy rozproszonej wyznacza się trajektorie dużej ilości ziaren w przepływającym płynie. Faza rozproszona może wymieniać pęd, energię i masę z otaczającym ją płynem. Model ten umożliwia modelowanie procesu suszenia. Do obliczeń procesu suszenia w suszarce multicyklonowej wykorzystano tzw. model dyfuzyjny oparty na równaniu (Ansys 2011):

$$
N_{i}=k_{c}\left(C_{i, s}-C_{i, \infty}\right)
$$

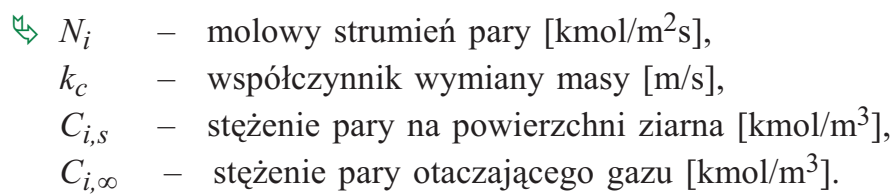


Do symulacji procesu suszenia rozdrobnionych wstępnie surowców energetycznych wytypowano słomę zbóż oraz węgiel brunatny. Obliczenia przeprowadzono dla następujących warunków:

- temperatura gazu do suszenia $170^{\circ} \mathrm{C}$;

- strumień gazu do suszenia $3200 \mathrm{~m}^{3} / \mathrm{h}(1,11 \mathrm{~kg} / \mathrm{s})$;

- strumień paliwa $500 \mathrm{~kg} / \mathrm{h}$;

- początkowa zawartość wilgoci: słoma $23 \%$ wag., węgiel brunatny $50 \%$ wag.;

- uziarnienie paliwa: słoma 1,5 i 2,5 mm; węgiel brunatny 0,$5 ; 1 ; 2 ; 3 \mathrm{~mm}$;

- temperatura początkowa paliwa $8^{\circ} \mathrm{C}$;

- temperatura otoczenia $10^{\circ} \mathrm{C}$;

- początkowa zawartość wilgoci w gazie do suszenia 1,5\% wag.

Podczas obliczeń uwzględniano straty ciepła do otoczenia.

Uzyskane $\mathrm{w}$ trakcie obliczeń temperatury i zawartości wilgoci dla surowca i gazu suszącego na poszczególnych stopniach suszenia zestawiono w tabeli 1. Prezentowane w artykule wartości wilgoci surowca dotyczą zawartości wilgoci całkowitej czyli procentu wagowego wody w stosunku do całkowitej masy paliwa.

Na rysunku 3 przedstawiono zawartość wilgoci w surowcu na wejściu i wyjściu dla każdego stopnia suszenia. Stopień odparowania węgla brunatnego jest mniejszy w stosunku do słomy, ale wynika to z bardzo wysokiej początkowej zawartości wilgoci węgla na poziomie $50 \%$. Jeśli bierze się pod uwagę masę odparowanej wody kształtuje się ona na podobnych poziomach. Stopień odparowania w istotny sposób uzależniony jest od uziarnienia surowca, co obrazuje rysunek 4. Można stwierdzić, że efektywne jest suszenie drobnych frakcji surowca, natomiast w przypadku większych średnic ziaren suszonego materiału stopień wysuszenia jest niezadawalający.

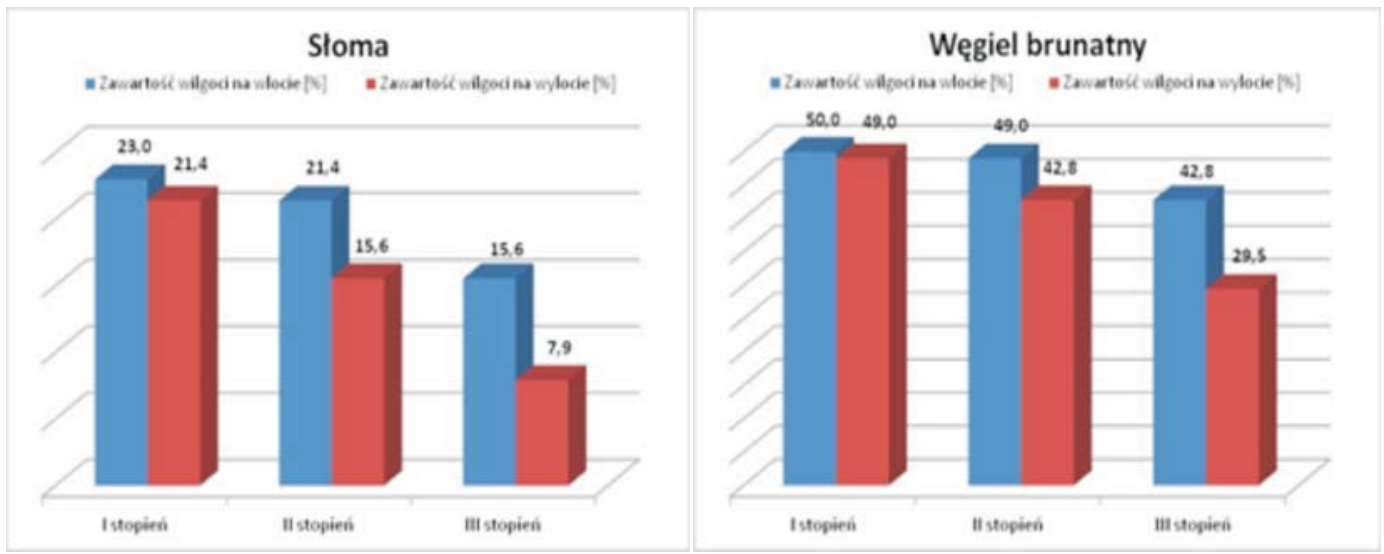

Rys. 3. Zmiana zawartości wilgoci surowca na poszczególnych stopniach suszarki multicyklonowej dla: słomy (uziarnienie $1,5 \mathrm{~mm}$ ) oraz węgla brunatnego (uziarnienie $0,5 \mathrm{~mm}$ )

Fig. 3. Moisture content of the raw material at different stages of a multi-cyclone dryer for straw (particle size $1.5 \mathrm{~mm}$ ) and brown coal (particle size $0.5 \mathrm{~mm}$ ) 
Tabela 1. Temperatury i zawartości wilgoci na poszczególnych stopniach suszenia dla słomy oraz węgla brunatnego

Table 1. Temperature and moisture content at different stages of a multi-cyclone dryer for straw and lignite

\begin{tabular}{|c|c|c|c|c|c|c|c|c|}
\hline \multirow[b]{2}{*}{ Wielkość } & \multicolumn{4}{|c|}{ Temperatura $\left[{ }^{\circ} \mathrm{C}\right]$} & \multicolumn{4}{|c|}{ Zawartość wilgoci [\% wag.] } \\
\hline & $\begin{array}{c}\text { surowca na } \\
\text { wlocie }\end{array}$ & $\begin{array}{c}\text { surowca na } \\
\text { wylocie }\end{array}$ & $\begin{array}{l}\text { gazu na } \\
\text { wlocie }\end{array}$ & $\begin{array}{l}\text { gazu na } \\
\text { wylocie }\end{array}$ & $\begin{array}{c}\text { surowca na } \\
\text { wlocie }\end{array}$ & $\begin{array}{c}\text { surowca na } \\
\text { wylocie }\end{array}$ & $\begin{array}{l}\text { gazu na } \\
\text { wlocie }\end{array}$ & $\begin{array}{l}\text { gazu na } \\
\text { wylocie }\end{array}$ \\
\hline \multicolumn{9}{|c|}{ Sloma o uziarnieniu $1,5 \mathrm{~mm}$} \\
\hline Ogólem & 8 & 46 & 170 & 92 & 23,0 & 7,9 & 1,5 & 3,5 \\
\hline I stopień & 8 & 42 & 111 & 92 & 23,0 & 21,4 & 3,3 & 3,5 \\
\hline II stopień & 42 & 45 & 138 & 111 & 21,4 & 15,6 & 2,4 & 3,3 \\
\hline III stopień & 45 & 46 & 170 & 138 & 15,6 & 7,9 & 1,5 & 2,4 \\
\hline \multicolumn{9}{|c|}{ Sloma o uziarnieniu $2,5 \mathrm{~mm}$} \\
\hline Ogólem & 8 & 45 & 170 & 117 & 23,0 & 14,8 & 1,5 & 2,7 \\
\hline I stopień & 8 & 39 & 133 & 150 & 23,0 & 22,3 & 1,5 & 2,1 \\
\hline II stopień & 39 & 43 & 150 & 133 & 22,3 & 19,1 & 2,1 & 2,6 \\
\hline III stopień & 43 & 45 & 170 & 117 & 19,1 & 14,8 & 2,6 & 2,7 \\
\hline \multicolumn{9}{|c|}{ Węgiel brunatny o uziarnieniu $0,5 \mathrm{~mm}$} \\
\hline Ogólem & 8 & 49 & 170 & 62 & 50,0 & 29,5 & 1,5 & 5,0 \\
\hline I stopień & 8 & 44 & 82 & 62 & 50,0 & 49,0 & 4,8 & 5,0 \\
\hline II stopień & 44 & 46 & 115 & 82 & 49,0 & 42,8 & 3,6 & 4,8 \\
\hline III stopień & 46 & 49 & 170 & 115 & 42,8 & 29,5 & 1,5 & 3,6 \\
\hline \multicolumn{9}{|c|}{ Węgiel brunatny o uziarnieniu 1 mm } \\
\hline Ogólem & 8 & 48 & 170 & 81 & 50,0 & 36,0 & 1,5 & 4,2 \\
\hline I stopień & 8 & 43 & 102 & 81 & 50,0 & 48,9 & 4,0 & 4,2 \\
\hline II stopień & 43 & 46 & 130 & 102 & 48,9 & 44,2 & 3,0 & 4,0 \\
\hline III stopień & 46 & 48 & 170 & 130 & 44,2 & 36,0 & 1,5 & 3,0 \\
\hline \multicolumn{9}{|c|}{ Węgiel brunatny o uziarnieniu 2 mm } \\
\hline Ogółem & 8 & 48 & 170 & 103 & 50,0 & 45,0 & 1,5 & 3,2 \\
\hline I stopień & 8 & 42 & 122 & 103 & 50,0 & 49,8 & 3,1 & 3,2 \\
\hline II stopień & 42 & 46 & 144 & 122 & 49,8 & 47,9 & 2,4 & 3,1 \\
\hline III stopień & 46 & 48 & 170 & 144 & 47,9 & 45,0 & 1,5 & 2,4 \\
\hline \multicolumn{9}{|c|}{ Węgiel brunatny o uziarnieniu 3 mm } \\
\hline Ogólem & 8 & 48 & 170 & 116 & $\mathbf{5 0 , 0}$ & 45,0 & 1,5 & 2,7 \\
\hline I stopień & 8 & 38 & 132 & 116 & 50,0 & 49,8 & 2,6 & 2,7 \\
\hline II stopień & 38 & 46 & 150 & 132 & 49,8 & 47,9 & 2,1 & 2,6 \\
\hline III stopień & 46 & 48 & 170 & 150 & 47,9 & 45,0 & 1,5 & 2,1 \\
\hline
\end{tabular}




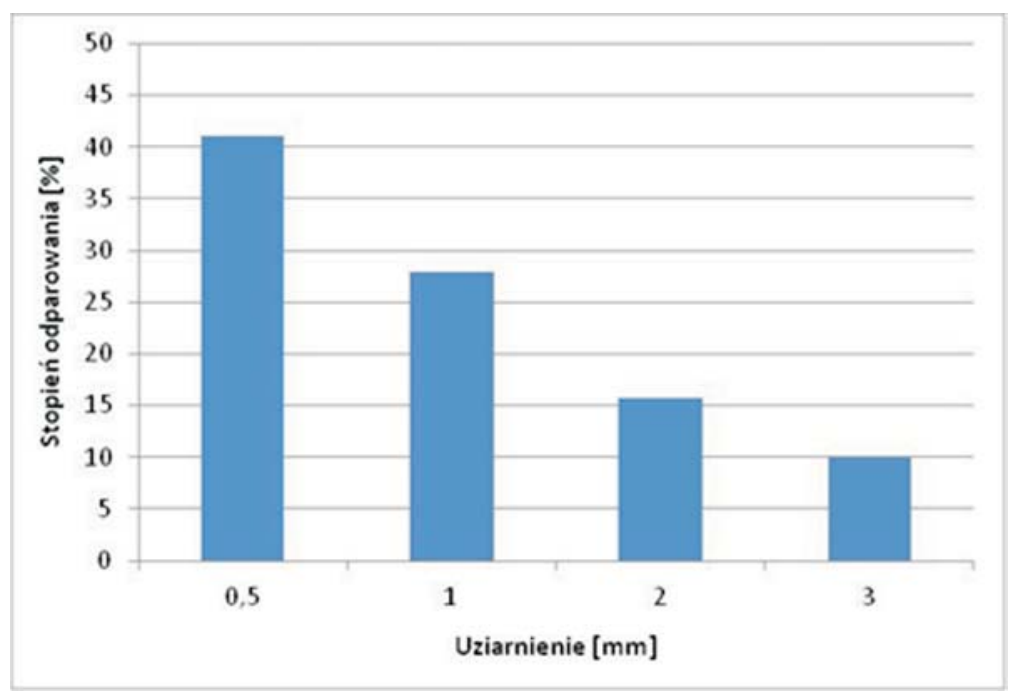

Rys. 4. Wpływ uziarnienia na stopień odparowania dla węgla brunatnego

Fig. 4. Influence of particle size on the evaporation degree for lignite

Na rysunku 5 przedstawiono przykładowe rozkłady prędkości, temperatury i ciśnienia oraz zawartości pary wodnej w gazie do suszenia wewnątrz suszarki multicyklonowej. Z kolei na rysunku 6 zaprezentowano rozkłady prędkości, temperatury oraz zawartości wilgoci dla ziaren suszonego paliwa. Przedstawione rozkłady dotyczą przypadku suszenia słomy o uziarnieniu $1,5 \mathrm{~mm}$.

Osiagana w suszarce prędkości gazu jest wystarczająca, aby wprawić w ruch wirowy rozdrobniony surowiec. Największe odparowanie zachodzi w trzecim stopniu suszarki, gdzie paliwo ma kontakt z gazem o największej temperaturze. Z kolei na pierwszym stopniu suszarki ma miejsce największy wzrost temperatury suszonego surowca. Czas przebywania słomy w każdym z cyklonów (rys. 7) jest zbliżony i wynosi około 1,5 s. W przypadku węgla brunatnego jest on bardziej zróżnicowany i kształtuje się w granicach 1,5-2,5 s, z tym że im większe uziarnienie tym większa wartość tego parametru. Ponadto ziarna najdłużej przebywają w trzecim stopniu suszarki, a najkrócej w pierwszym.

Obliczony według równań 2 i 3 (Vorobiev i in. 1965) współczynnik wymiany ciepła w suszarce multicyklonowej wynosi około $250 \mathrm{~W} / \mathrm{m}^{2} \mathrm{~K}$, co pozwala na intensywną wymianę ciepła oraz znaczne zintensyfikowanie procesu suszenia.

$$
\begin{gathered}
\alpha=0,4 \frac{\lambda}{d_{e}} F e^{0,895} \\
F e=d_{e} \sqrt[3]{\frac{4 g}{3 v}}\left(\frac{\rho_{s}}{\rho_{g}}-1\right)
\end{gathered}
$$



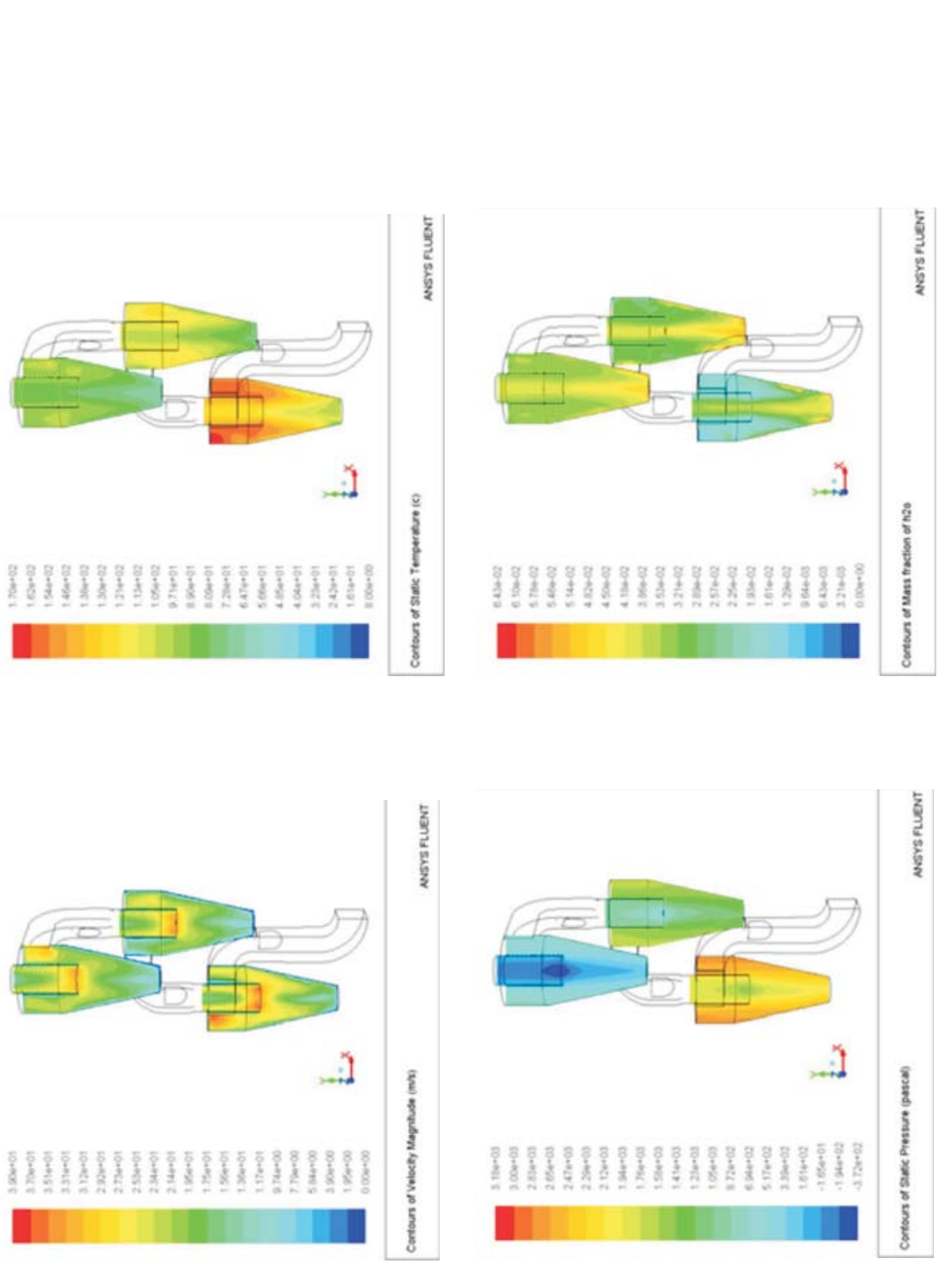

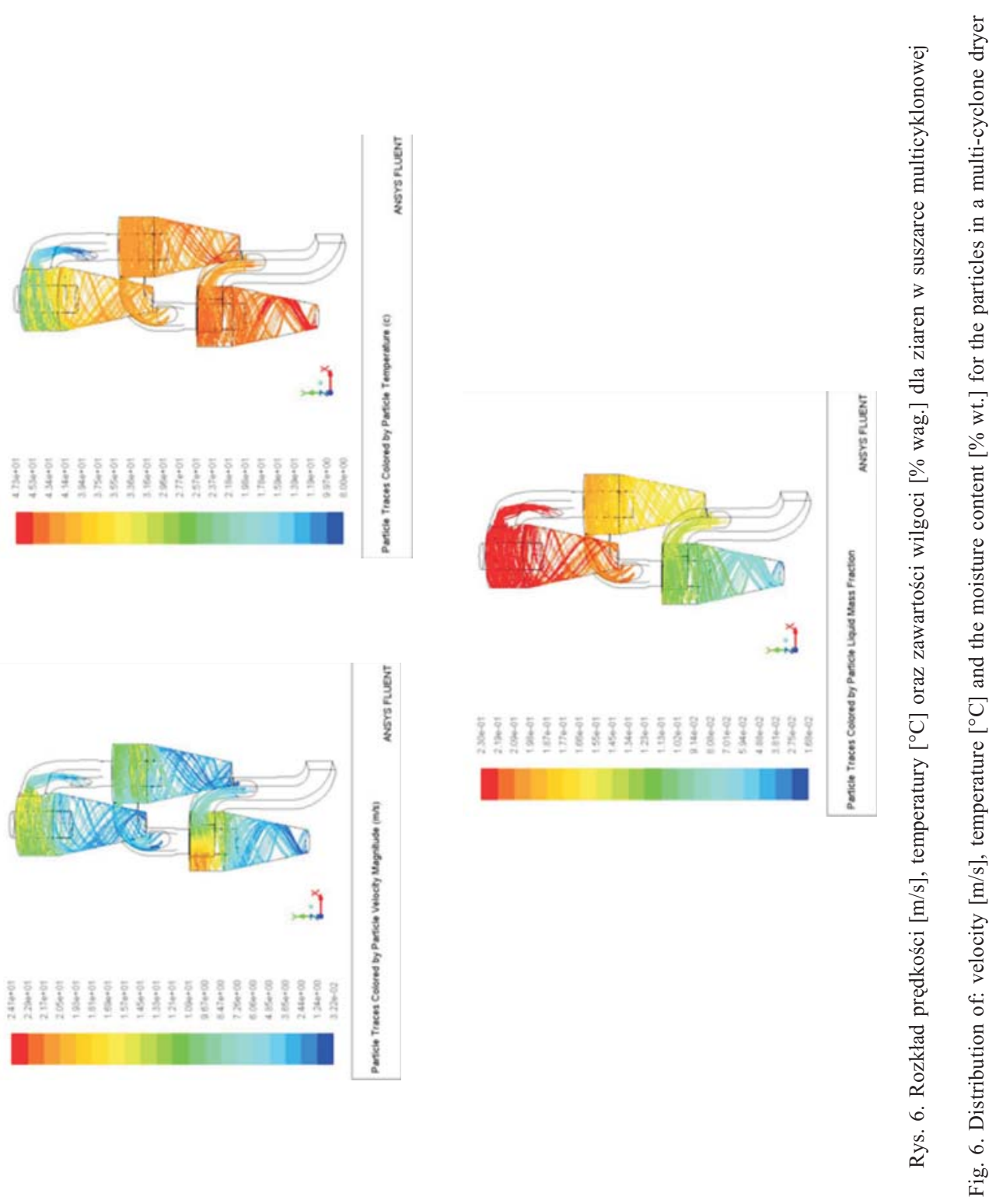


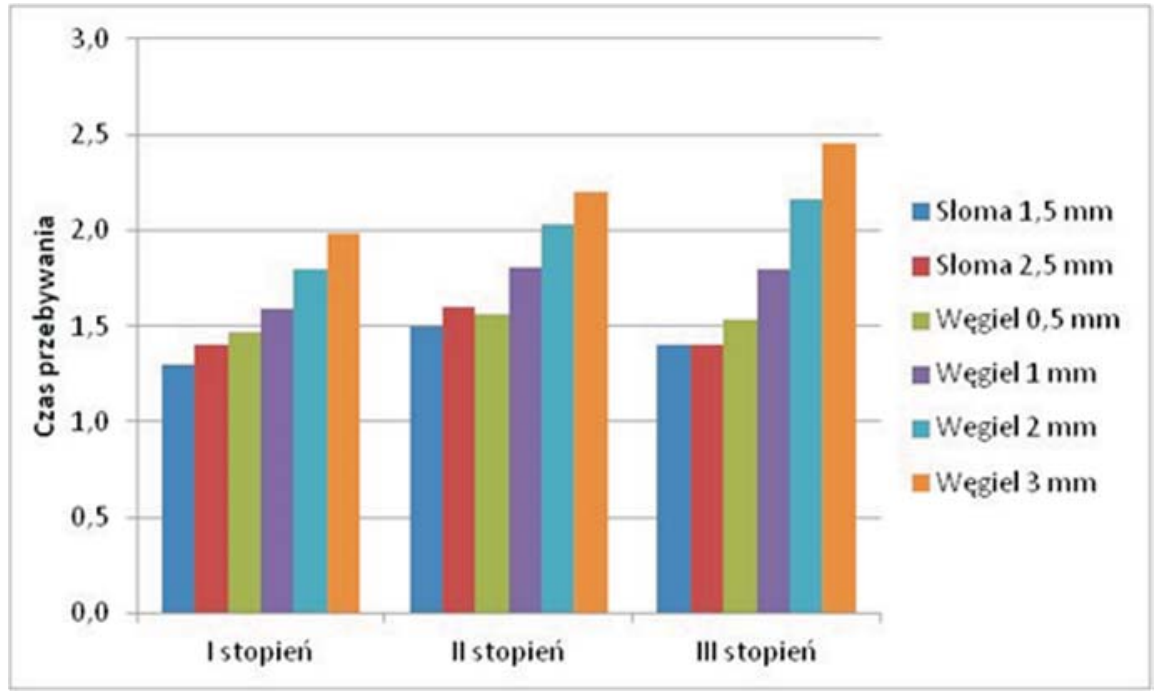

Rys. 7. Czas przebywania surowca [s] w poszczególnych cyklonach

Fig. 4. The residence time [s] of particles for each cyclone

$\Leftrightarrow \lambda-$ przewodność cieplna gazu $\left[\mathrm{W} / \mathrm{m}^{2} \mathrm{~K}\right]$,

$d_{e}-$ średnica równoważna ziarna $[\mathrm{m}]$,

$\rho_{s}-$ gęstość surowca $\left[\mathrm{kg} / \mathrm{m}^{3}\right]$,

$\rho_{g}-$ gęstość gazu $\left[\mathrm{kg} / \mathrm{m}^{3}\right]$,

$\mathrm{Fe}$ - liczba Fiodorowa [-],

$\alpha-$ współczynnik wymiany ciepła $\left[\mathrm{W} / \mathrm{m}^{2} \mathrm{~K}\right]$,

$v$ - lepkość kinematyczna gazu $\left[\mathrm{m}^{2} / \mathrm{s}\right]$.

Na rysunku 8 przedstawiono schemat suszarki multicyklonowej z naniesionymi wynikami pomiarów temperatury gazów i suszonej słomy prowadzonych na stanowisku oraz rezultatami uzyskanymi podczas obliczeń symulacyjnych. Podczas pomiarów uzyskano odparowanie wilgoci ze słomy z poziomu $23 \%$ do $7 \%$. Zaprezentowane wartości są wartością średnią z pomiarów wykonanych w czasie suszenia przez około 15 min. Pomiary rozpoczęto po 30 min. pracy suszarki.

Stopień odparowania uzyskiwany podczas obliczeń i w trakcie pomiarów jest zbliżony (odpowiednio 6,7 oraz $7,9 \%$ zawartości wilgoci w surowcu po suszeniu). W przypadku temperatury surowca różnica pomiędzy wartościami obliczonymi a uzyskanymi podczas pomiarów jest niewielka (odpowiednio 46 i $52^{\circ} \mathrm{C}$ ). Większe różnice można zauważyć porównując temperaturę gazu uzyskaną w trakcie pomiaru oraz z obliczeń symulacyjnych $i$ tak na wylocie z suszarki temperatura zmierzona $\left(62^{\circ} \mathrm{C}\right)$ jest mniejsza od obliczonej $\left(92^{\circ} \mathrm{C}\right)$. Uzyskane różnice mogą wynikać z zastosowania do obliczeń średnicy zastępczej ziarna, kiedy w rzeczywistości mamy do czynienia z rozkładem uziarnienia. Mniejsze ziarna po odparowaniu nagrzewają się, co może skutkować wyższą temperaturą podczas pomiaru. 


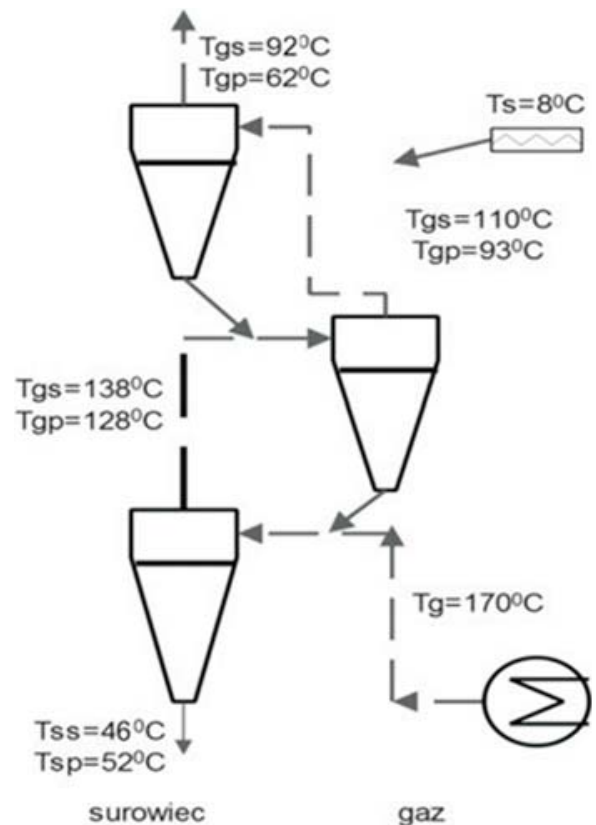

Rys. 8. Zestawienie temperatury surowca i gazów uzyskanych w trakcie pomiarów oraz podczas obliczeń symulacyjnych dla suszenia rozdrobnionej słomy o średnim rozmiarze ziarna $1,5 \mathrm{~mm}$

$\mathrm{Tg}$ - temperatura gazu $\left[{ }^{\circ} \mathrm{C}\right], \mathrm{Ts}$ - temperatura surowca $\left[{ }^{\circ} \mathrm{C}\right]$, indeks ,s” oznacza wynik symulacji, natomiast indeks ,„p" wartość uzyskaną z pomiarów

Fig. 8. A compilation of raw material and gas temperature obtained during the measurements and the simulation calculations for drying straw with an average particle size of $1.5 \mathrm{~mm}$ :

$\mathrm{Tg}$ - gas temperature $\left[{ }^{\circ} \mathrm{C}\right]$, Ts - the raw material temperature $\left[{ }^{\circ} \mathrm{C}\right]$; the index "s" means the result of the simulation, while the index " $p$ " indicates the value obtained from the measurements

Niestety, specyfika modelowania suszarki multicyklonowej (trzy stopnie) uniemożliwia wprowadzenie paliwa uwzględniające dystrybucję jego uziarnienia. Rozbieżności mogą również wynikać z założonych wartości do obliczeń, w szczególności strumienia gazu oraz zawartości początkowej wilgoci w gazie do suszenia, które mogą odbiegać od rzeczywistych. Ponadto podczas obliczeń symulacyjnych nie brano pod uwagę tarcia ziaren suszonego materiału o wewnętrzną ściankę cyklonu, co może mieć istotny wpływ na proces suszenia. Mimo różnic przeprowadzone obliczenia symulacyjne są istotnym źródłem wiedzy odnośnie funkcjonowania suszarki multicyklonowej i przydatnym narzędziem do analizy jakościowej procesów w niej zachodzących.

\section{Podsumowanie}

Przeprowadzone próby na stanowisku doświadczalnym suszenia biomasy oraz węgla brunatnego oraz obliczenia symulacyjne potwierdziły słuszność przyjętej koncepcji suszenia 
z wykorzystaniem cyklonów w układzie szeregowym. Suszarka multicyklonowa wykazała zdolność do obniżenia o $15 \%$ wilgoci w słomie (zawartość początkowa $23 \%$ ) przy zastosowaniu niskiej temperatury suszenia, tj. $170{ }^{\circ} \mathrm{C}$ dla zastępczego rozmiaru ziarna $1,5 \mathrm{~mm}$. W przypadku suszenia rozdrobnionego węgla brunatnego - przy założonym zastępczym rozmiarze ziarna $0,5 \mathrm{~mm}$ i użyciu temperatury gazów suszących $170^{\circ} \mathrm{C}$ - ilość wilgoci zmniejszyła się o 21\% (zawartość początkowa 50\%). Należy tutaj wspomnieć, że istotnym parametrem wpływającym na stopień odparowania jest średnica podawanego surowca. Efektywne jest suszenie drobnych frakcji surowca, natomiast w przypadku większych średnic ziaren suszonego materiału stopień wysuszenia jest niezadawalający, co potwierdza, że przed suszeniem powinien on być rozdrabniany. Dla odpowiednio rozdrobnionego paliwa badana suszarka multicyklonowa wykazała dużą dynamikę procesu suszenia, która wynosi $4 \%$ na s w przypadku suszenia słomy i $3 \%$ na s dla węgla brunatnego.

Modelowanie numeryczne CFD jest przydatnym narzędziem do analizy pracy suszarki multicyklonowej, dzięki któremu uzyskano szereg informacji na temat jej funkcjonowania.

Praca została wykonana $w$ trakcie realizacji projektu CoalGas WP5 „Development of coal and biomass preparation technology for gasification and combustion processes" finansowanego w ramach KIC InnoEnergy

\section{LITERATURA}

Akpinar, E. i Bicer, Y. 2005. Modeling of the drying of eggplants in thin-layers. International Journal of Food Science and Technology 40, s. 273-281.

Ansys 2011. Ansys Fluent Theory Guide.

Brennan i in. 2009 - Brennan, M., Holtham, P. i Narasimha, M. 2009. CFD Modeling Of Cyclone Separators: Validation Against Plant Hydrodynamic Performance, Seventh International Conference on CFD in the Minerals and Process Industries, CSIRO, Melbourne, Australia, 9-11 December 2009.

Bunyawanichakul i in. 2006 - Bunyawanichakul, P., Kirkpatrick, M.P., Sargison, J.E., Walker, G.J. 2006. A Three -Dimensional Simulation of a Cyclone Dryer. Fifth International Conference on CFD in the Process Industries CSIRO, Melbourne, Australia 13-15 December 2006.

Corrêi in. 2004 - Corrê, J.L.G, Graminho, D.R., Silva, M.A. i Nebra, S.A. 2004. The Cyclonic Dryer - A Numerical And Experimental Analysis of the Influence of Geometry on Average Particle Residence Time, Brazilian Journal of Chemical Engineering Vol. 21, No. 01, s. 103-112, January-March 2004.

Dzik T. i Grzebieluch, A. 2012. Suszarka cyklonowa biomasy roślinnej. WIPO ST 10/c PL 2012, 398095.

Dzik T. i Grzebieluch, A. 2012. Cyclon Dryer for plant biomass. PCT/PL2012/000113.

Hryniewicz i in. 2012 - Hryniewicz, M., Dzik, T. i Czerski, G. 2012. Biomass compaction with low coals a way of its preparation for the gasification process. A Monograph „Development of Coal, Biomass and Wastes Gasification Technologies with Particular in Chemical Seqestration of $\mathrm{CO}_{2}$ ”, s. 67-78.

Karcz, A. i Strugała, A. 2008. Zwiększenie szans wykorzystania krajowej bazy węgli koksowych poprzez działania technologiczne w zakresie przygotowania mieszanek wsadowych. Gospodarka Surowcami MineralnymiMineral Resources Managemen t. 24, z. 1/1, s. 5-18.

Mirowski, T. i Surma, T. 2008. Paliwa biomasowe w sektorze wytwarzania energii elektrycznej i ciepła w Polsce. Gospodarka Surowcami Mineralnymi-Mineral Resources Managemen t. 24, z. 3/3, s. 211-221.

Mujumdar, A.S. 2011. Classification and Selection of Industrial Dryers. Handbook of industrial drying, 2nd ed.Vol. 1. New York. 
Wade, A. 1998. Report on Biomass Drying Technology. National Renewable Energy Laboratory November 1998 , NREL/TP-570-25885.

Wang i in. 2003. B. Wang, B., Xu, D.L., Xiao, G.X., Chu, K.W. i Yu, A.B. 2003. Numerical Study Of Gas-Solid Flow In A Cyclone Separator, Third International Conference on CFD in the Minerals and Process Industries, CSIRO, Melbourne, Australia,10-12 December 2003.

Westbergh, K. 2007. 3D-model of a Dryer Cyclone Examensarbete i maskinteknik, Institutionen Ingenjörshögskolan, Högskolan i Borås No. 2.

Vorobiev i in. 1965 - Vorobiev, H., Mazurov, D. i Sokolov, A. 1965. Tieplotechnologiczeskije procesy i aparatura silikatnych proizvodstv. Vysszaja Szkola. Moskwa 1965.

Żarczyński i in. 2013. - Żarczyński, P., Strugała A., Sobolewski, A., Kaczmarek, W. 2013. Analiza możliwości poprawy efektywności energetycznej procesu koksowania przez wdrożenie operacji podsuszania. Gospodarka Surowcami Mineralnymi-Mineral Resources Management t. 29, z. 3, s. 151-165.

\title{
BADANIE SUSZENIA SHOMY I WĘGLA BRUNATNEGO W SUSZARCE MULTICYKLONOWEJ
}

\author{
Słowa kluczowe
}

paliwa kompozytowe, suszenie węgla i biomasy, suszarka

\section{Streszczenie}

Proces suszenia jest niezbędnym elementem podczas wytwarzania paliw kompozytowych z biomasy i węgla. Omawiana suszarka multicyklonowa jest oryginalnym rozwiązaniem konstrukcyjnym opracowanym i opatentowanym przez AGH, które może być wykorzystane w trakcie przygotowanie surowca do procesu scalania. W artykule przedstawiono wyniki pomiarów suszenia rozdrobnionej słomy i węgla brunatnego w doświadczalnej suszarce multicyklonowej oraz rezultaty obliczeń symulacyjnych jej pracy. Do utworzenia modelu numerycznego CFD (Computational Fluids Dynamics) procesu suszenia w suszarce multicyklonowej wykorzystano oprogramowanie ANSYS Fluent. Dzięki modelowaniu numerycznemu CFD uzyskano informacje na temat pracy i funkcjonowania wymienionej suszarki. Zaprezentowano szereg uzyskanych w trakcie obliczeń rezultatów, tj.: temperatury i zawartości wilgoci dla surowca i gazu suszącego, zmianę zawartości wilgoci surowca na poszczególnych stopniach suszarki, wpływ uziarnienia paliwa na stopień jego odparowania, rozkłady najważniejszych parametrów pracy suszarki dla gazu do suszenia i suszonych ziaren oraz czas przebywania surowca w poszczególnych stopniach suszarki. Ponadto wyznaczono współczynnik wymiany ciepła w suszarce multicyklonowej, który wynosi do $250 \mathrm{~W} /\left(\mathrm{m}^{2} \mathrm{~K}\right)$. Przeprowadzone próby na stanowisku doświadczalnym suszenia biomasy i węgla brunatnego oraz obliczenia symulacyjne potwierdziły słuszność przyjętej koncepcji suszenia z wykorzystaniem cyklonów w układzie szeregowym. Suszarka wykazała zdolność do obniżenia o 15\% wilgoci w słomie przy zastosowaniu niskiej temperatury suszenia, $\mathrm{tj} .170^{\circ} \mathrm{C}$ dla zastępczego rozmiaru ziarna $1,5 \mathrm{~mm} . \mathrm{W}$ przypadku suszenia rozdrobnionego węgla brunatnego dla rozmiaru zastępczego ziarna $0,5 \mathrm{~mm}$, ilość wilgoci zmniejszyła się o $21 \%$. Badana suszarka multicyklonowa wykazała dużą dynamikę procesu suszenia, która wynosi $3 \% / \mathrm{s}$ w przypadku suszenia rozdrobnionej słomy i $4 \% / \mathrm{s}$ dla rozdrobnionego węgla brunatnego. 


\section{STUDY OF THE DRYING PROCESS OF STRAW AND LIGNITE IN A MULTI-CYCLONE DRYER}

$$
\text { Key words }
$$

composite fuel, coal and biomass drying, drying process

\section{Abstract}

The drying process is an essential part of the production of composite fuels from biomass and coal. The presented multi-cyclone dryer is an original design solution developed and patented by AGH, which can be used during the preparation of raw material for the unification process. This article presents the results of measurements of the particulate straw and lignite drying in a multi-cyclone dryer, and the results of simulation calculations of the dryer's performance. The ANSYS Fluent software was used to create a CFD (Computational Fluids Dynamics) numerical model of the drying process in a multi-cyclone dryer. The CFD numerical modelling provided information about the performance and operation of the dryer. Key results obtained during the calculations include the following: the temperature and moisture content of the raw material and drying gas, the change in the moisture content of the raw material for each stage of the dryer, the influence of fuel particle size on the degree of evaporation, the distribution of the most important parameters of the dryer's performance for drying gas and dried particles, and the residence time of the raw material for each stage of the dryer. Moreover, the heat transfer coefficient in the multi-cyclone dryer was determined, which is up to $250 \mathrm{~W} /\left(\mathrm{m}^{2} \mathrm{~K}\right)$. The conducted experimental tests of biomass and lignite drying in the dryer, as well as the simulation calculations, confirmed the validity of the approach for drying with the use of cyclones arranged in series. The dryer demonstrated the ability to release $15 \%$ of the moisture from the straw with the use of a low drying temperature, i.e. $170^{\circ} \mathrm{C}$ for the sample particle size of $1.5 \mathrm{~mm}$. In the case of particulate lignite drying for the substitute particle size of $0.5 \mathrm{~mm}$, the amount of evaporated moisture was $21 \%$. The examined multi-cyclone dryer demonstrated high dynamics in the drying process, at $3 \%$ per $\mathrm{s}$ in the case of particulate straw drying and $4 \%$ per s for particulate lignite. 
